\title{
Why is Your Team More Creative Than Mine? The Influence of Shared Mental Models on Intra-group Conflict, Team Creativity and Effectiveness
}

Citation for published version (APA):

Santos, C. M., Uitdewilligen, S., \& Passos, A. M. (2015). Why is Your Team More Creative Than Mine? The Influence of Shared Mental Models on Intra-group Conflict, Team Creativity and Effectiveness. Creativity and Innovation Management, 24(4), 645-658. https://doi.org/10.1111/caim.12129

Document status and date:

Published: 01/12/2015

DOI:

10.1111/caim.12129

Document Version:

Publisher's PDF, also known as Version of record

Document license:

Taverne

Please check the document version of this publication:

- A submitted manuscript is the version of the article upon submission and before peer-review. There can be important differences between the submitted version and the official published version of record.

People interested in the research are advised to contact the author for the final version of the publication, or visit the DOI to the publisher's website.

- The final author version and the galley proof are versions of the publication after peer review.

- The final published version features the final layout of the paper including the volume, issue and page numbers.

Link to publication

\footnotetext{
General rights rights.

- You may freely distribute the URL identifying the publication in the public portal. please follow below link for the End User Agreement:

www.umlib.nl/taverne-license

Take down policy

If you believe that this document breaches copyright please contact us at:

repository@maastrichtuniversity.nl

providing details and we will investigate your claim.
}

Copyright and moral rights for the publications made accessible in the public portal are retained by the authors and/or other copyright owners and it is a condition of accessing publications that users recognise and abide by the legal requirements associated with these

- Users may download and print one copy of any publication from the public portal for the purpose of private study or research.

- You may not further distribute the material or use it for any profit-making activity or commercial gain

If the publication is distributed under the terms of Article $25 \mathrm{fa}$ of the Dutch Copyright Act, indicated by the "Taverne" license above, 


\section{Why is Your Team More Creative Than Mine? The Influence of Shared Mental Models on Intra-group Conflict, Team Creativity and Effectiveness}

\section{Catarina Marques Santos, Sjir Uitdewilligen and Ana Margarida Passos}

In competitive and dynamic contexts team members need to be creative to ensure that teams achieve high levels of performance and feel satisfied with their work. At the same time, team members need to have a shared understanding regarding relevant aspects related to task accomplishment and team interaction. In this study we investigate the mediating mechanisms of intra-group conflict and creativity in the relationship between shared mental models and team effectiveness (team performance and satisfaction). We tested our model in a sample of 161 teams (735 individuals) performing in a management simulation. We collected data at three time points. Our results suggest that high shared mental models are related to low levels of intra-group conflict, foster creativity, and in turn improve team performance and satisfaction. These findings contribute to a scarce thematic - the relationship between shared mental models and creativity - emphasizing the importance of a shared understanding for creativity and team effectiveness.

\section{Introduction}

\footnotetext{
The organizational contexts in which teams 1 operate are becoming increasingly competitive. As a result teams often need to be creative to achieve their goals, present new solutions or suggest new products (Burke et al., 2006). Researchers have analyzed team factors that foster team creativity, such as task interdependence, team size and cohesion (Hülsheger, Anderson \& Salgado, 2009). Yet, an in-depth investigation of the impact of team cognitive factors, such as shared mental models, is lacking. Shared mental models (SMM) refer to a common understanding among the team members about relevant task and team aspects of their work (Klimoski \& Mohammed, 1994). Although empirical studies show that SMM foster a variety of team processes and outcomes, such as coordination,
}

adaptation and performance (e.g., Mathieu et al., 2000; Santos \& Passos, 2013; Uitdewilligen, Waller \& Pitariu, 2013), empirical studies that analyze the effect of SMM on creativity are still missing. As SMM imply a common understanding shared by team members, it is important to analyze whether SMM inhibit creative ideas because team members share the same ideas and do not discuss different points of view, or whether SMM potentiate creative ideas because they facilitate effective co-ordination and co-operation among the team members.

Literature about the impact of SMM on creativity is scarce. On the one hand, it has been argued that SMM may stifle creativity (Skilton \& Dooley, 2010). When team members have too much overlap in their understanding about task and team aspects of work, this may reduce their ability to innovate and to be crea- 
tive. On the other hand, previous studies suggest a positive effect of SMM on adaptation, which is closely related to creativity and innovation because teams need to solve problems and create new products in order to be able to adapt (Burke et al., 2006).

Intra-group conflict is likely to play a role in the relationship between SMM and creativity. Conflict results from the tension among team members and involves discrepancies and incompatible goals (Jehn \& Mannix, 2001; De Dreu \& Weingart, 2003). Intra-group conflict may hamper creativity, impede team members' ability to develop new ideas and thereby decrease team effectiveness (Jehn, 1995; Simons \& Peterson, 2000; De Dreu \& Weingart, 2003; de Wit, Greer \& Jehn, 2012). A recent study showed that SMM similarity diminish the level of relationship conflict and in turn improve team effectiveness (Santos \& Passos, 2013). However, empirical studies that analyze the relationships among SMM, conflict, creativity and effectiveness are needed.

In the present study we investigate the mediating mechanisms of intra-group conflict and team creativity in the relationship between SMM and team effectiveness (team performance and satisfaction). We analyze four types of intra-group conflict: task, relationship, process and temporal conflict. Analyzing the mediating role of intra-group conflict and creativity allows us to integrate and test alternative theories on how SMM impact team effectiveness (Mathieu, DeShon \& Bergh, 2008).

\section{Shared Mental Models}

Previous research suggests that SMM impact team performance and satisfaction (e.g., Mathieu et al., 2000, 2010; Santos \& Passos, 2013). Performance is an objective criterion that indicates team-level actual task accomplishment. Team satisfaction is an affective concept that indicates the degree to which team members are satisfied with the team experience (McGrath, 1964; Hackman, 1987). SMM foster team effectiveness because they enable team members to anticipate the needs and actions of other team members and to adapt their actions to align with their colleagues as well as with the demands of the task (Cannon-Bowers, Salas \& Converse, 1993; DeChurch \& Mesmer-Magnus, 2010). When team members have SMM, they make efficient use of their information and knowledge, produce efficient collective responses to immediate task requirements, and subsequently are able to achieve high levels of performance and feel satisfied with the team experience (Cannon-Bowers, Salas \&
Converse, 1993; DeChurch \& MesmerMagnus, 2010; Santos \& Passos, 2013).

\section{Shared Mental Models and Intra-group Conflict}

Intra-group conflict is a process that occurs when team members perceive their interests and values to be incongruent with those of other members of the team (Jehn \& Mannix, 2001; DeChurch, Mesmer-Magnus \& Doty, 2013). Three different types of intra-group conflict have been identified in the literature: task, relationship and process conflict (Jehn, 1995, 1997). Task conflict refers to disagreements among team members related to the content of the tasks, such as differences regarding ideas or opinions (Jehn, 1995). Relationship conflict refers to arguments about personal and social issues that are not directly related to the task and that involve negative emotions and tension (Jehn, 1995; De Dreu \& van Vianen, 2001). Process conflict refers to differences on the procedures by which the task should be accomplished, the distribution of responsibilities, and the structure of delegation within the team (Jehn, 1997). Recently, scholars have added a fourth type of conflict: temporal conflict, which refers to intra-group disputes about time, the duration of a task, and the length of time the team should spend on a specific task or goal (Mohammed \& Nadkarni, 2011; Standifer et al., 2015).

Different perspectives exist regarding the impact of intra-group conflict on team functioning. Previous empirical studies consistently show that relationship conflict and process conflict limit team members' ability to share, exchange and process relevant information, and that they distract team members from engaging in effective task execution (Jehn, 1997; De Dreu \& Weingart, 2003; Passos \& Caetano, 2005; de Wit, Greer \& Jehn, 2012; Santos \& Passos, 2013). Research on temporal conflict suggests that it increases ambiguity about task deadlines and the sequence of task accomplishment, which disrupts co-ordination processes and increases team members' frustration (Mohammed \& Nadkarni, 2011; Standifer et al., 2015). Findings about task conflict, however, are inconsistent. Although initial research suggests that task conflict may facilitate innovativeness and high-quality team decisions (Jehn, 1995; Amason, 1996), a metaanalysis by De Dreu and Weingart (2003) shows that task conflict has disruptive effects on team effectiveness. Nevertheless, a recent metaanalysis did not show a strong and negative association between task conflict and team performance (de Wit, Greer \& Jehn, 2012). 
SMM play an important role in the development of intra-group conflict by stimulating constructive conflict and avoiding disruptive conflict. As teams that have SMM have a common understanding of the task goals, procedures and strategies, this facilitates coordination among the team members and fosters knowledge about what other members need to accomplish their task. Therefore members are able to openly discuss ideas and different viewpoints arising over the team lifecycle (Cannon-Bowers, Salas \& Converse, 1993; DeChurch \& Mesmer-Magnus, 2010; Santos, Uitdewilligen \& Passos, 2015). When team members have SMM and discuss ideas that are aligned with the task and team aspects of their work, they are likely to increase their effectiveness in executing their task. In short, when team members have SMM, they can engage in task conflict situations, solve them, make optimal decisions, achieve high levels of performance, and feel satisfied with their work.

Hypothesis 1(a) Task conflict mediates the relationship between SMM and team effectiveness (team performance and satisfaction).

Team members who have SMM are focused on task accomplishment and discuss aspects related to the task and team interaction that really matter for effectiveness. Consequently, teams avoid disagreements based on personal issues, on team members' responsibilities and on the length of time the team should spend on a specific task or goals and thereby achieve high levels of performance and member satisfaction (Simons \& Peterson, 2000; Santos \& Passos, 2013; Standifer et al., 2015). Thus, teams that have SMM experience low levels of relationship, process and temporal conflict and achieve high levels of performance and their members feel satisfied with their team.

Hypothesis 1(b) Relationship conflict, 1(c) process conflict and $1(d)$ temporal conflict mediate the relationship between SMM and team effectiveness (team performance and satisfaction).

\section{Shared Mental Models and Team Creativity}

Creativity refers to the process of 'coming up with fresh ideas for changing products, services, and processes so as to better achieve the organization's goals' (Amabile et al., 2005, p. 367). Creativity requires originality and effectiveness, as 'original things must be effective to be creative' (Runco \& Jaeger, 2012, p. 92). Past research has demonstrated that team input variables, such as task interdependence and job-relevant diversity stimulate team crea- tive processes (West, 2002; van der Vegt \& Janssen, 2003; Hülsheger, Anderson \& Salgado, 2009). Team processes, such as communication patterns, task orientation and intra-group conflict, also have an impact on creativity and innovation (Jehn, 1995; West \& Anderson, 1996; De Dreu, 2006).

Despite these important findings in creativity research, a relevant discussion exists on the effect of SMM on creativity that needs clarification. Skilton and Dooley (2010) pose that SMM may stifle creativity. They argue that particularly when team members work together on creative projects, they internalize and synchronize their SMM, which over time become resistant to change. In subsequent projects, team members may avoid discussing novel ideas and diverging points of view in order to avoid conflict and not to disrupt the status quo (Skilton \& Dooley, 2010). In short, Skilton and Dooley (2010) argue that the common understanding shared by team members inhibits innovative and creative ideas.

Contrastingly, a number of empirical studies have shown that SMM positively foster team adaptation, which includes innovation as a sub-facet (Burke et al., 2006; Resick et al., 2010; Uitdewilligen, Waller \& Pitariu, 2013). When team members have SMM, they are able to adapt their routines when they are confronted with complex and dynamic task environments (Kozlowski et al., 2001; Resick et al., 2010). Hülsheger, Anderson and Salgado (2009) argue that when teams have SMM, the positive relationship between job-relevant diversity and innovation might be strong, because then team members' working styles are aligned, they agree on team norms, and they are co-ordinated and willing to co-operate with each other (Kozlowski \& Bell, 2003; Bledow et al., 2009). Furthermore, team members who have SMM are able to generate, create and implement new ideas or products that are aligned and in accordance with the requirements of the task and the needs of the team (Burke et al., 2006; Hülsheger, Anderson $\&$ Salgado, 2009). Consequently, teams achieve high levels of performance and team members feel satisfied.

Although team factors directly impact team creativity, they also impact the extent to which individuals can be creative, which in turn facilitates team effectiveness. Research suggests that when team members 'are open to new ideas, constructively challenge one another, effectively communicate and provide feedback, successfully manage conflict, trust and help each other, and share a commitment to their work' (DiLiello, Houghton \& Dawley, 2011, p. 155), they perceive support for creativity, which fosters team and organizational 


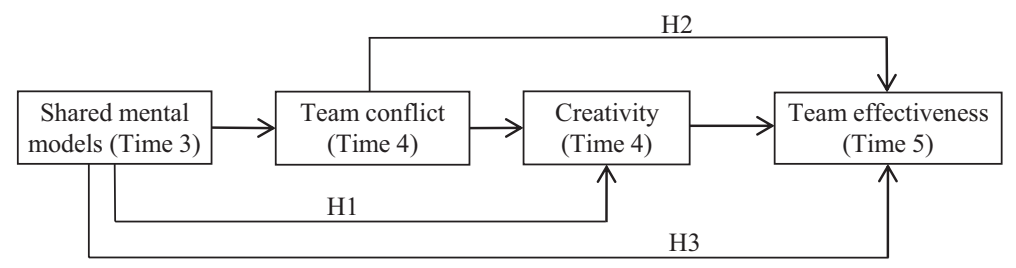

Figure 1. Hypothesized model

innovation and effectiveness (Amabile, 1988; DiLiello, Houghton \& Dawley, 2011). In this sense, we argue that a team work environment, where members have a similar understanding regarding relevant team and task aspects of their work, fosters team members' creativity. SMM and creativity, in turn, have a positive impact on the ability of the team to perform and the extent to which its members feel satisfied with the team.

Hypothesis 2 Creativity positively mediates the relationship between SMM and team effectiveness (team performance and satisfaction).

\section{Shared Mental Models, Intra-group Conflict and Team Creativity}

A number of empirical studies have given special attention to the relationship between task conflict and creativity (Pelled, Eisenhardt \& Xin, 1999; Chen, 2006; De Dreu, 2006; Badke-Schaub, Goldschmidt \& Meijer, 2010). Findings suggest that task conflict fosters creativity because when team members disagree about central components of the task, they are likely to explore opposing ideas, and discuss diverging viewpoints, which enhances the generation of new ideas (Chen, 2006; Badke-Schaub, Goldschmidt \& Meijer, 2010). Conversely, relationship conflict hampers creativity because it limits team members' ability to communicate, discuss and share information (Jehn, 1995; Simons \& Peterson, 2000; Chen, 2006).

We argue that teams that have SMM, and experience high levels of task conflict and low levels of relationship, process and temporal conflict, are likely to create new solutions for problems or unexpected situations and to achieve high levels of team effectiveness. As team members share a common understanding of relevant aspects of their work, they discuss issues related to task accomplishment and team goals, and they avoid disruptive conflicts (Jehn, 1995; Simons \& Peterson, 2000; Santos \& Passos, 2013). Consequently, as team members think about new ideas and solutions, they achieve high levels of performance and feel satisfied with the team. Thus, we expect a relationship between SMM, team conflict, creativity and effectiveness.

Hypothesis 3(a) Task conflict, 3(b) relationship conflict, 3(c) process conflict, and 3(d) temporal conflict and creativity sequentially mediate the relationship between SMM and team effectiveness.

The research model is represented in Figure 1.

\section{Method}

\section{Participants}

A total of 161 teams (735 individuals) participated in this study. All teams were enrolled in a national management and strategy simulation for a 5-week period. The teams were composed of workers (42.6 per cent), university students (41.1 per cent), or a mix of workers and students (16.4 per cent). Team sizes ranged from three to five members, with an average of 4.67 (s.d. $=0.62$ ). The average age was 29 years (s.d. $=8.42$ ) and 67.4 per cent of the participants were male.

\section{Simulation}

We collected data using the business simulation the Global Management Challenge ${ }^{\circledR}$. In this simulation teams run fictitious companies that have the objective of gaining the highest share price on the simulated stock exchange. The simulation has been running for over 30 years, and many top companies encourage their employees to take part in it. The simulation comprises four stages: first round, second round, national final and international final. We collected data in the first round of the simulation that takes place across five consecutive weeks and involves a larger number of teams. Before the beginning of the simulation, teams receive a manual that explains how the simulation works, and a management report about the companies they will run. This information can be used over the simulation. Further, approximately one month before the beginning of the simulation, participating teams enrol in two training sessions. The 
teams were assigned to a group consisting of a maximum of eight teams representing a competitive market, in which they had to compete with one another. The simulation lasts five weeks, with each week simulating three months. In each quarter teams make decisions on the marketing, production, personnel, purchasing and finance of their fictional company. The simulation algorithm computes the effect of these decisions on the companies' financial indicators, their share price and on their ranking relative to the other teams. This information is presented to the team in the form of a management report to the teams after each quarter.

Team members are free to assemble their own team. Because members might know each other from their university (for student teams), or from their jobs (worker teams), some teams may have worked together before. The mix teams were formed by students and workers. For these teams it is less likely that members have worked together previously. Companies may ask students to join their teams as part of a recruitment process as this enables them to analyse the behaviours, competencies and skills of these students.

\section{Procedure}

Team members answered two different on-line questionnaires during the simulation. Performance was provided by the company responsible for the simulation. The company authorized data collection and informed participants about the research, whereas the authors of the study were responsible for sending the link to the questionnaires and for collecting the data. The link to the questionnaires was sent to the team members by e-mail at different time moments in the simulation period. Participants answered the questionnaires individually before receiving the management report with the feedback about their decisions.

\section{Measures}

\section{Shared Mental Models}

Based on the four types of models identified by Cannon-Bowers and colleagues (1993), we developed a four-item scale to evaluate SMM. On a 7-point Likert scale ( $1=$ totally disagree, $7=$ totally agree) the participants indicated how much they agreed with each of the statements. A list of the statements is provided in the Appendix. We performed an exploratory factor analysis which revealed only one factor with 81.24 per cent of variance explained. A confirmatory factor analysis (CFA) executed in Mplus (Muthén \& Muthén, 1998-2010) indicated an acceptable goodness of fit index, with all indices falling within acceptable ranges $(\mathrm{Hu}$ \& Bentler, 1999; Schreiber et al., 2006): $\chi^{2}$ $(2)=55.73, p=0.00$; RMSEA (root mean square error of approximation) $=0.00$; CFI (comparative fit index) $=0.97$; TLI (Tucker-Lewis index) $=0.90$; SRMR (standardized root mean square residual $)=0.02$. SMM were measured in the third week of the competition $(\alpha=0.92)$.

\section{Intra-group Conflict}

Relationship, task and process conflicts were measured using 12 items from the Intra-group Conflict Scale by Jehn $(1995,1997)$. Temporal conflict was measured with a modified threeitem scale by Yang (2009) based on the original process conflict scale developed by Jehn (1995) and Shah and Jehn (1993). On a 7-point scale ( $1=$ never, $7=$ always $)$, the participants indicated how often each behaviour occurred in their team. A list of the statements is provided in the Appendix. Conflict was measured in the fourth week of the competition $\left(\alpha_{\text {relationship }}=\right.$ $\left.0.96 ; \alpha_{\text {task }}=0.87 ; \alpha_{\text {process }}=0.92 ; \alpha_{\text {temporal }}=0.95\right)$.

\section{Creativity}

Creativity was measured with the selfperceived creativity and creative self-efficacy ( 5 and 6 items respectively) scales by DiLiello and colleagues (2011). On a 7-point scale $(1=$ totally disagree; $7=$ totally agree $)$, the participants rated the extent to which they agreed with each sentence. A list of the sentences is provided in the Appendix. We used the two scales together, because an exploratory factor analysis revealed only one factor with 78.14 per cent of variance explained. A CFA was implemented by Mplus (Muthén \& Muthén, 1998-2010) which presented an acceptable goodness of fit index as all indices fell within acceptable ranges $(\mathrm{Hu} \&$ Bentler, 1999; Schreiber et al., 2006): $\chi^{2}(35)=327.39, p=0.00$; RMSEA $=0.00 ; \mathrm{CFI}=0.95$; $\mathrm{TLI}=0.93$; $\mathrm{SRMR}=$ 0.03 . Creativity was measured in the fourth week of the competition $(\alpha=0.97)$.

\section{Performance}

Performance was operationalized as the share price at the end of the simulation. The share price was given in Euros and was automatically calculated by the simulation software. The simulation also automatically provided the team's relative position in the group, ranging from first to eighth. We operationalized performance by recoding the share price on a 1- to 8-point scale through the percentile values - we asked for the cut-off points for eight equal groups. We created a new variable based on the values of the eight groups, 
which was used in the mediation analyses. The lowest share prices correspond to lower values and the highest share prices correspond to higher values. This performance measure was discussed and constructed on the basis of recommendations of the developers of the management simulation.

\section{Team Satisfaction}

Team satisfaction was measured with eight items adapted from the Job Satisfaction Scale by Spector (1997). On a 7-point scale (1 = very dissatisfied; $7=$ very satisfied), the participants rated how much they were satisfied with different aspects of their teamwork. A list of the statements is provided in the Appendix. Satisfaction was measured in the fifth week of the competition $(\alpha=0.98)$.

\section{Control Variables}

We included team size, team composition (workers, university students or both), and familiarity as control variables in our analyses (van Knippenberg \& Schippers, 2007; Humphrey, Morgeson \& Mannor, 2009). We controlled for team size because it can impact a team's ability to establish and build upon mental models. Team size was measured as the number of members in the team. For the control variable team composition, we transformed the categorical variable into two dummy variables, using the workers as a baseline, as they represented more teams in the competition. Familiarity was measured as the percentage of team members that already knew each other before the start of the simulation.

\section{Results}

\section{Aggregation}

The level of analysis in this study was the team. Thus, all individual survey responses were aggregated to the team level for further analysis (Costa et al., 2013). To justify aggregation, we computed $\mathrm{R}_{\mathrm{wg} \text { (j) }}$ (James, Demaree \& Wolf, 1993), designed for multiple-item scales, and intra-class correlation coefficients (ICC) (Bliese, 2000). All the values were in accordance with the required criteria (see Table 1). Therefore, individual answers were aggregated to the team level.

\section{Hypotheses Testing}

Table 1 provides the means, standard deviations and the correlations for all study variables at the team level. The results show a negative and significant correlation between mental models and the four types of intragroup conflict. The results show a positive and significant correlation between SMM and creativity $(r=0.53, p<0.01)$, as well as satisfaction $(r=0.60, p<0.01)$. The four types of conflict were negative and significantly correlated with creativity and satisfaction. Creativity was positively and significantly correlated with team effectiveness $\left(r_{\text {performance }}=0.21, p<0.01\right.$; $\left.r_{\text {satisfaction }}=0.52, p<0.01\right)$. Regarding the control variables, familiarity was positively and significantly correlated with mental models $(r=0.20, p<0.05)$.

To evaluate our research model with multiple sequential mediators, we used the PROCESS macro, developed by Hayes (2013). This macro allows for testing the indirect effects of SMM on effectiveness through conflict and creativity, even when there is no association between SMM and effectiveness. Team size, team composition and familiarity were entered as control variables. We re-sampled 5,000 times and examined for 95 per cent confidence intervals (CI). We can assume that the indirect effects are significant and that mediation occurred if zero falls outside of the 95 per cent confidence interval (Preacher \& Hayes, 2008).

Table 2 provides the path estimates for the models. Hypotheses $1(\mathrm{a}-\mathrm{d})$ propose that intragroup conflict mediates the relationship between SMM and team effectiveness. Intragroup conflict mediated the relationship between SMM and satisfaction (task: 0.05 $[\mathrm{CI}=0.01,0.13]$; relationship: $0.11[\mathrm{CI}=0.05$, 0.22]; process: $0.09[\mathrm{CI}=0.03,0.19]$; temporal: $0.10[\mathrm{CI}=0.04,0.20])$. Intra-group conflict did not mediate the relationship between SMM and performance (task: $-0.13[\mathrm{CI}=-0.40,0.02]$; relationship: $-0.00[\mathrm{CI}=-0.25,0.24]$; process: $-0.08[\mathrm{CI}=-0.38,0.14]$; temporal: $0.02[\mathrm{CI}=$ $-0.27,0.30])$. Hypotheses $1 \mathrm{a}, 1 \mathrm{~b}, 1 \mathrm{c}$ and $1 \mathrm{~d}$ were partially supported.

Hypothesis 2 proposes that creativity positively mediates the relationship between SMM and team effectiveness. The results showed that creativity mediated the relationship of SMM with performance $(0.37$ [CI $=0.09,0.73])$ and satisfaction $(0.14 \quad[\mathrm{CI}=0.05,0.27])$. Hypothesis 2 was supported.

Hypotheses $3(\mathrm{a}-\mathrm{d})$ pose that intra-group conflict and creativity sequentially mediate the relationship between SMM and team effectiveness. The results showed that task conflict and creativity mediated the relationship of SMM with performance $(0.04[\mathrm{CI}=0.01,0.16])$ and satisfaction $(0.02[\mathrm{CI}=0.01,0.05])$. Hypothesis 3a was partially supported. Relationship conflict and creativity mediated the relationship of SMM with performance $(0.08 \quad[C I=0.01$, $0.24])$ and satisfaction $(0.03[\mathrm{CI}=0.01,0.07])$. 


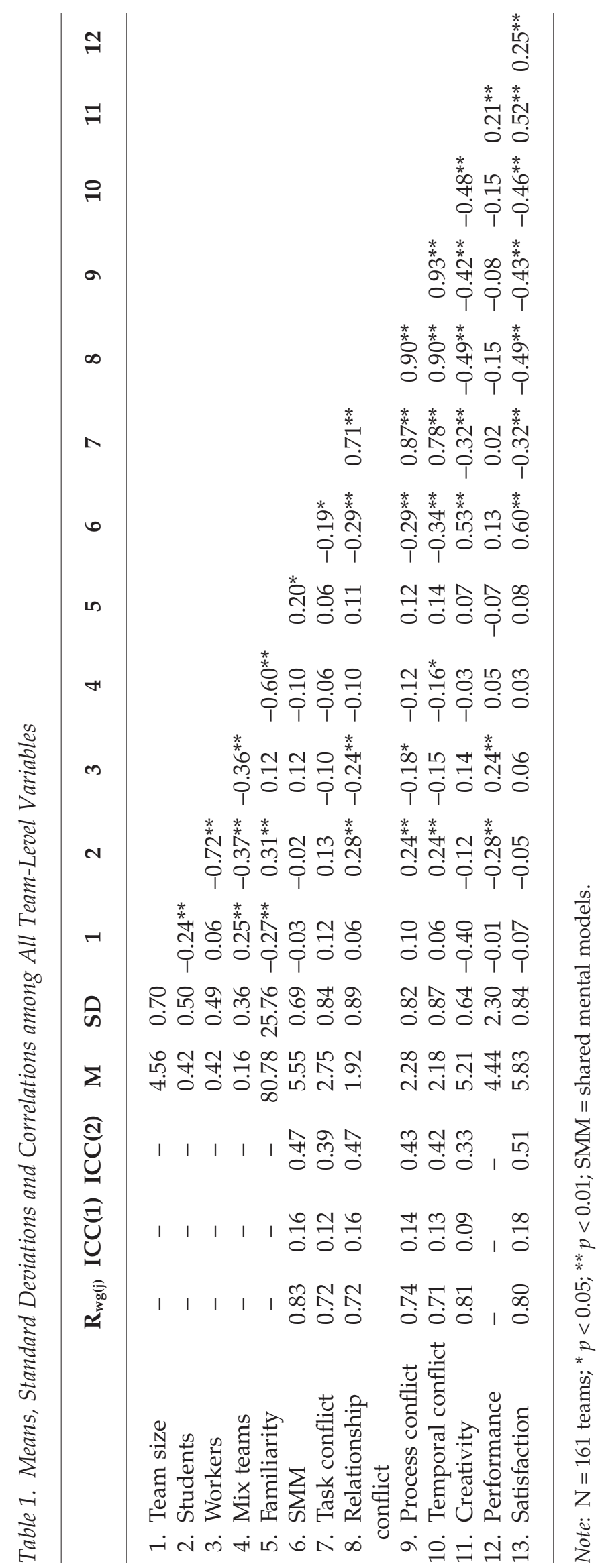


Table 2. Model Path Estimates for Models with Task, Relationship, Process and Temporal Conflict

\begin{tabular}{|c|c|c|c|c|}
\hline & \multicolumn{2}{|c|}{ Performance model } & \multicolumn{2}{|c|}{ Satisfaction model } \\
\hline & Coefficient & $p$ value & Coefficient & $p$ value \\
\hline \multicolumn{5}{|l|}{ Model with task conflict } \\
\hline $\mathrm{SMM} \rightarrow$ Effectiveness $^{\mathrm{a}}$ & 0.25 & 0.44 & 0.68 & 0.00 \\
\hline $\mathrm{SMM} \rightarrow$ Effectiveness $^{\mathrm{b}}$ & -0.03 & 0.94 & 0.47 & 0.00 \\
\hline SMM $\rightarrow$ Task conflict & -0.35 & 0.00 & -0.36 & 0.00 \\
\hline SMM $\rightarrow$ Creativity & 0.46 & 0.00 & 0.43 & 0.00 \\
\hline Task conflict $\rightarrow$ Creativity & -0.14 & 0.05 & -0.18 & 0.01 \\
\hline Task conflict $\rightarrow$ Effectiveness & 0.37 & 0.14 & -0.14 & 0.05 \\
\hline Creativity $\rightarrow$ Effectiveness & 0.80 & 0.03 & 0.32 & 0.00 \\
\hline \multicolumn{5}{|l|}{ Model with relationship conflict } \\
\hline SMM $\rightarrow$ Effectiveness $^{\mathrm{a}}$ & 0.25 & 0.44 & 0.68 & 0.00 \\
\hline SMM $\rightarrow$ Effectiveness $^{\mathrm{b}}$ & -0.11 & 0.78 & 0.45 & 0.00 \\
\hline SMM $\rightarrow$ Relationship conflict & -0.43 & 0.00 & -0.43 & 0.00 \\
\hline SMM $\rightarrow$ Creativity & 0.39 & 0.00 & 0.38 & 0.00 \\
\hline Relationship conflict $\rightarrow$ Creativity & -0.27 & 0.00 & -0.26 & 0.00 \\
\hline Relationship conflict $\rightarrow$ Effectiveness & -0.00 & 0.99 & -0.26 & 0.00 \\
\hline \multirow{2}{*}{\multicolumn{5}{|c|}{ Model with process conflict }} \\
\hline & & & & \\
\hline $\mathrm{SMM} \rightarrow$ Effectiveness $^{\mathrm{a}}$ & 0.25 & 0.44 & 0.67 & 0.00 \\
\hline SMM $\rightarrow$ Effectiveness $^{\mathrm{b}}$ & -0.06 & 0.87 & 0.45 & 0.00 \\
\hline SMM $\rightarrow$ Process conflict & -0.43 & 0.00 & -0.43 & 0.00 \\
\hline SMM $\rightarrow$ Creativity & 0.41 & 0.00 & 0.40 & 0.00 \\
\hline Process conflict $\rightarrow$ Creativity & -0.23 & 0.00 & -0.23 & 0.00 \\
\hline Process conflict $\rightarrow$ Effectiveness & 0.19 & 0.50 & -0.22 & 0.00 \\
\hline Creativity $\rightarrow$ Effectiveness & 0.78 & 0.04 & 0.27 & 0.00 \\
\hline \multicolumn{5}{|l|}{ Model with temporal conflict } \\
\hline SMM $\rightarrow$ Effectiveness $^{\mathrm{a}}$ & 0.25 & 0.44 & 0.68 & 0.00 \\
\hline SMM $\rightarrow$ Effectiveness $^{\mathrm{b}}$ & -0.11 & 0.77 & 0.45 & 0.00 \\
\hline SMM $\rightarrow$ Temporal conflict & -0.50 & 0.00 & -0.48 & 0.00 \\
\hline SMM $\rightarrow$ Creativity & 0.38 & 0.00 & 0.37 & 0.00 \\
\hline Temporal conflict $\rightarrow$ Creativity & -0.26 & 0.00 & -0.27 & 0.00 \\
\hline Temporal conflict $\rightarrow$ Effectiveness & -0.03 & 0.91 & -0.21 & 0.00 \\
\hline Creativity $\rightarrow$ Effectiveness & 0.68 & 0.08 & 0.26 & 0.01 \\
\hline
\end{tabular}

Note: $\mathrm{N}=161$ teams; SMM = shared mental models; The coefficients refer to the unstandardized regression coefficient.

a The total effect of SMM on team effectiveness without the inclusion of mediator variables.

$\mathrm{b}$ The total effect of SMM on team effectiveness with the inclusion of mediator variables.

Hypothesis $3 b$ was supported. Process conflict and creativity mediated the relationship of SMM with performance $(0.08[C I=0.01,0.20])$ and satisfaction $(0.03[\mathrm{CI}=0.01,0.06])$. These results support Hypothesis 3c. Temporal conflict and creativity mediated the relationship of SMM with performance $(0.09[\mathrm{CI}=0.01$, $0.27])$ and satisfaction $(0.03[\mathrm{CI}=0.01,0.08])$. Hypothesis $3 \mathrm{~d}$ was supported.

\section{Discussion}

This study presents important findings for teams functioning in highly competitive and dynamic environments where team members need to be creative and present innovative solutions. Our study shows the importance of SMM in constraining the level of intra-group conflict, in stimulating creativity and in fostering team effectiveness.

Our findings suggest that SMM diminish the level of conflict and in turn improve team satisfaction. However, in contrast with our hypothesis, SMM did not improve team performance by decreasing intra-group conflict. These results are contrary to our expectations, which postulated that when team members have SMM they engage in task conflict because they are able to discuss ideas and divergent viewpoints that arise over the team lifecycle as 
they clearly know the task goals and procedures as well as the needs of other members. Our findings may suggest that as team members share an understanding about the task procedures, they previously define all the aspects related to task execution, and discuss different ideas and points of view. Thus, by the middle of the team lifecycle all these aspects have been clearly defined and they do not need to discuss these again.

SMM diminish the level of intra-group conflict and in turn improve team satisfaction. Our research reveals important findings on a mediator that is scarcely analysed in SMM research. It appears that SMM impede discussions about personal issues, deadlines and task delegation because team members are focused on task accomplishment. Consequently, team members are more likely to feel satisfied with the teamwork experience (Rentsch \& Klimoski, 2001). However, SMM did not improve team performance via team conflict. These results are contrary to our expectations, and may suggest that intra-group conflict is more relevant as a mediating mechanism in the relationship between SMM and team satisfaction than in the relationship between SMM and performance. The social issues, deadlines, task procedures and task delegations that teams discuss in the middle of the team lifecycle are important for the level of satisfaction team members feel at the end of the task accomplishment, but they do not impact the level of performance.

Finally, our findings show that intragroup conflict and creativity act as mediating mechanisms between SMM and team effectiveness. These results are in accordance with our expectations and show that as team members have SMM, they do not engage in conflict behaviours, which allows them to be creative and in turn to achieve high levels of performance and feel satisfied with the team.

\section{Theoretical and Research Implications}

Our research represents a contribution to the study of SMM by showing that this cognitive construct positively influences team creativity, and in turn team effectiveness. Thus far, different perspectives exist regarding the impact of SMM on creativity. While some authors argue that SMM block creativity (Skilton \& Dooley, 2010), other authors argue that when team members have SMM they are more likely to be creative because they are co-ordinated, willing to co-operate with each other, and they trust and help each other (Hülsheger, Anderson \& Salgado, 2009; DiLiello, Houghton \& Dawley, 2011). Our findings support the latter perspective and show that in organizational contexts where team members have SMM, team members develop creative ideas, because their working styles are aligned, and they agree on important aspects of taskwork and teamwork (Hülsheger, Anderson \& Salgado, 2009). Therefore, team members are able to achieve high levels of performance and feel satisfied with their work. However, more research about these topics is needed.

Our study analyses temporal conflict, which represents a recent dimension of intra-group conflict with important implications for team functioning. Increasingly, teams are pressured by time, work to tight deadlines and need to distribute their time and resources over different projects. Thus, it is important that teams avoid temporal disagreements and know how to work from the beginning of the team lifecycle. More research about temporal conflict is needed.

\section{Practical Implications}

Our study offers a number of insights that companies may use in order to help their teams to improve their creativity and effectiveness. First, our study offers insights into the importance of fostering SMM and creativity in organizational teams. Our findings show that when team members have SMM, team members develop creative ideas that are in accordance with the requirements of the task and the needs of the team. Furthermore, our findings show that teams need to avoid conflict situations to be creative and to perform optimally. This implies that teams would benefit from receiving information about the importance of developing SMM and avoiding and managing conflicts.

Previous research suggests that the development of SMM may be promoted by having team members engage in collective planning prior to task performance (Stout et al., 1999). In addition, a number of studies emphasize the important role the team leader plays in fostering the development of SMM. Marks, Zaccaro and Mathieu (2000) found that team leaders can help teams to develop SMM by providing briefings before the actual performance episode. Lorinkova, Pearsall and Sims (2013) found that teams with empowering leaders develop more similar mental models than teams with directive leaders. So, when creativity is important for goal attainment, team leaders may be instructed to develop an empowering leadership style, in which they involve all team members in the goal-setting and decision-making processes.

Some interventions can be used particularly for (interdisciplinary) teams that work 
virtually, for instance, international teams. A mind-mapping intervention can be used where team members should, individually, think about or write the main actions and/or the main information they need to perform well in the task (Rentsch et al., 2010). Then, each team member should explain to each other the meaning of each action. In the next step, team members should collectively make the connection among those concepts, thereby creating a shared mental representation. Face-to-face teams may do this intervention together and make a 'physical' mind map, for instance on a whiteboard. International or virtual teams may develop this shared knowledge object, for instance in a video-conference, using virtual collaboration software. This intervention is likely to facilitate team members' understanding of each other's work, align their strategy, and increase the knowledge of each other skills, leading to a shared knowledge about the main aspects of the task and teamwork.

To prevent conflict situations, team leaders and team members need to learn strategies that could help them to discuss important aspects of work, deadlines and task delegation in a way, and at a time, that would not interfere with team functioning. Team members and leaders need to develop conflict management competencies and learn how and when to use those strategies to prevent dysfunctional conflict situations. Behfar et al. (2008) identified a number of strategies that can help teams to reduce conflict and improve performance and satisfaction. For instance, to prevent task conflict, team members can discuss or debate different ideas and opinions in order to achieve consensus, ensuring that all members have a chance to explain their viewpoints. To prevent relationship conflict, team members can be trained to avoid taking disagreements in a personal way. Conflict management training can help team members focus on the content of the arguments instead of on the possibly unpleasant style in which these are formulated. To prevent process conflict, team members can schedule meetings in which they discuss and ensure the quality of the work, and prevent or plan for potential future problems. They can also assign a member (e.g., the team leader) to allocate responsibilities, or they can provide team members with autonomy to choose which specific task they want to execute (Behfar et al., 2008). Preventing temporal conflict is not only important for teams that work together in the same place and time, but is particularly important for international or virtual teams (Montoya-Weiss, Massey \& Song, 2001). Both types of teams can use temporal co-ordination mechanisms that help them to communicate and co-ordinate effectively. For instance, they can create rules and procedures to prevent time management issues, they can establish consensus on the allocation of time to the different team tasks, and they can schedule deadlines to align the pace and effort among the team members (Montoya-Weiss, Massey \& Song, 2001; Behfar et al., 2008).

\section{Limitations and Directions for Future Research}

The management simulation is an artificial scenario that has some limitations for the external validity of the findings. For instance, team members may not be fully engaged in the simulation, or may not work for the collective goal. However, similar to real teams in organizations, teams need to make several complex decisions where team members need to focus on different indicators to achieve a specific objective, and need to work together in an episodic way over five weeks (Mathieu et al., 2000; Mathieu \& Rapp, 2009). This scenario, as in the real world, requires high levels of interaction and co-ordination. In the real world we could expect that teams would share a stronger SMM than in the simulation because team members have known each other for a long period of time, and they are familiar with the tasks they need to perform, as well as with each other's preferences and abilities. Thus, the effect of SMM fostering creativity, reducing intra-group conflict and, in turn, improving team effectiveness could be stronger than in the simulation.

We analysed creativity through individual level measures: self-perceived creativity and creative self-efficacy, which were aggregated to the team level. As our study is a team-level study, we should analyse creativity through a team-level measure (Costa et al., 2013). However, individuals still need to be creative for a team to perform well. As we measured and considered team members' perception of their own creativity, our findings can help team members and leaders to identify creativity gaps and help human resources managers to design training programmes and interventions in order to develop some untrained creative skills and competencies (DiLiello, Houghton \& Dawley, 2011). Despite this advantage, future studies should analyse creativity through team level measures.

The creativity measure we used in this study reflects self-perceived creativity and creative self-efficacy, which may refer to a fixed characteristic of the person. Despite research showing that team factors influence individuals' perception of their own creativity (Amabile, 1988; DiLiello, Houghton \& Dawley, 
2011), fixed characteristics of the person normally are not easily influenced by the environment. We could measure creativity before the teamwork experience has started to test its relationship with mental models, conflict and team effectiveness.

Although our study shows that SMM do not impede creative ideas, it is important to understand when too much overlapping of mental models becomes disruptive to creativity and to team functioning. If all team members have an exact replication of each other's mental models, the creation of new solutions and ideas can be threatened (Salas, Sims \& Burke, 2005). Future studies should analyse these questions.

\section{Conclusion}

In increasingly competitive contexts, teams need to share an understanding about the way they work and interact. Simultaneously they need to present new ideas and solutions in order to achieve high levels of performance and compete with other teams and organizations. Our study provides important implications that should be taken into account by team leaders and organizational managers who want that their teams to present creative ideas, experience low levels of conflict and achieve high levels of effectiveness.

\section{References}

Amabile, T.M. (1988) A Model of Creativity and Innovation in Organizations. Research in Organizational Behavior, 19, 123-67.

Amabile, T.M., Barsade, S.G., Mueller, J.S. and Staw, B.M. (2005) Affect and Creativity at Work. Administrative Science Quarterly, 50, 367-403.

Amason, A.C. (1996) Distinguishing the Effects of Functional and Dysfunctional Conflict on Strategic Decision Making: Resolving a Paradox for Top Management Teams. Academy of Management, 39, 123-48.

Badke-Schaub, P., Goldschmidt, G. and Meijer, M. (2010) How Does Cognitive Conflict in Design Teams Support the Development of Creative Ideas? Creativity and Innovation Management, 19, 119-33.

Behfar, K.J., Peterson, R.S., Mannix, E.A. and Trochim, W.M.K. (2008) The Critical Role of Conflict Resolution in Teams: A Close Look at the Links between Conflict Type, Conflict Management Strategies, and Team Outcomes. Journal of Applied Psychology, 93, 170-88.

Bledow, R., Frese, M., Anderson, N., Erez, M. and Farr, J. (2009) A Dialectic Perspective on Innovation: Conflicting Demands, Multiple Pathways, and Ambidexterity. Industrial and Organizational Psychology, 2, 305-37.
Bliese, P.D. (2000) Within-Group Agreement, NonIndependence, and Reliability: Implications for Data Aggregation and Analysis. In Klein, K.J. and Kozlowski S.W.J. (eds.), Multilevel Theory, Research, and Methods in Organizations. JosseyBass, San Francisco, CA, pp. 349-81.

Burke, C.S., Stagl, K.C., Salas, E., Pierce, L. and Kendall, D. (2006) Understanding Team Adaptation: A Conceptual Analysis and Model. Journal of Applied Psychology, 91, 1189-207.

Cannon-Bowers, J.A., Salas, E. and Converse, S. (1993) Shared Mental Models in Expert Team Decision-Making. In Castellan, Jr. N.J. (ed.), Individual and Group Decision-Making: Current Issues. Lawrence Erlbaum, Hillsdale, NJ, pp. 221-46.

Chen, M-H. (2006) Understanding the Benefits and Detriments of Conflict on Team Creativity Process. Creativity and Innovation Management, 15, 105-16.

Costa, P.L., Graça, A.M., Marques-Quinteiro, P., Santos, C.M., Caetano, A. and Passos, A.M. (2013) Multilevel Research in the Field of Organizational Behavior: An Empirical Look at 10 Years of Theory and Research. SAGE Open, 3, 1-17.

DeChurch, L.A. and Mesmer-Magnus, J.R. (2010) The Cognitive Underpinnings of Effective Teamwork: A Meta-Analysis. Journal of Applied Psychology, 95, 32-53.

DeChurch, L.A., Mesmer-Magnus, J.R. and Doty, D. (2013) Moving beyond Relationship and Task Conflict: Toward a Process-State Perspective. Journal of Applied Psychology, 98, 559-78.

De Dreu, C.K.W. (2006) When Too Little or Too Much Hurts: Evidence for a Curvilinear Relationship between Task Conflict and Innovation in Teams. Journal of Management, 32, 83-107.

De Dreu, C.K.W. and van Vianen, A.E.M. (2001) Managing Relationship Conflict and the Effectiveness of Organizational Teams. Journal of Organizational Behavior, 22, 309-28.

De Dreu, C.K.W. and Weingart, L.R. (2003) Task versus Relationship Conflict, Team Performance, and Team Member Satisfaction: A Meta-Analysis. Journal of Applied Psychology, 88, 741-9.

de Wit, F.R.C., Greer, L.L. and Jehn, K.A. (2012) The Paradox of Intragroup Conflict: A Meta-Analysis. Journal of Applied Psychology, 97, 360-90.

DiLiello, T.C., Houghton, J.D. and Dawley, D. (2011) Narrowing the Creativity Gap: The Moderating Effects of Perceived Support for Creativity. Journal of Psychology, 145, 151-72.

Hackman, J.R. (1987) The Design of Work Teams. In Lorsch, J.W. (ed.), Handbook of Organizational Behaviour. Prentice Hall, New York, pp. 315-42.

Hayes, A.F. (2013) An Introduction to Mediation, Moderation, and Conditional Process Analysis: A Regression-Based Approach. Guilford Press, New York.

Hu, L. and Bentler, P.M. (1999) Cut of Criteria for Fit Indexes in Covariance Structure Analysis: Conventional Criteria versus New Alternatives. Structural Equation Modeling, 6, 1-55.

Hülsheger, U.R., Anderson, N. and Salgado J.F. (2009) Team-Level Predictors of Innovation at Work: A Comprehensive Meta-Analysis Spanning Three Decades of Research. Journal of Applied Psychology, 94, 1128-45. 
Humphrey, S.E., Morgeson, F.P. and Mannor, M.J. (2009) Developing a Theory of the Strategic Core of Teams: A Role Composition Model of Team Performance. Journal of Applied Psychology, 94, 48-61.

James, L.R., Demaree, R.J. and Wolf, G. (1993) Rwg: An Assessment of Within Group Interrater Agreement. Journal of Applied Psychology, 78, 306-9.

Jehn, K.A. (1995) A Multi Method Examination of the Benefits and Detriments of Intragroup Conflict. Administrative Science Quarterly, 40, 25682.

Jehn, K.A. (1997) A Qualitative Analysis of Conflict Types and Dimensions in Organizational Groups. Administrative Science Quarterly, 42, 530-57.

Jehn, K.A. and Mannix, E. (2001) The Dynamic Nature of Conflict: A Longitudinal Study of Intragroup Conflict and Group Performance. Academy of Management Journal, 44, 238-51.

Klimoski, R. and Mohammed, S. (1994) Team Mental Model: Construct or Metaphor? Journal of Management, 20, 403-37.

Kozlowski, S.W.J. and Bell, B.S. (2003) Work Groups and Teams in Organizations. In Borman, W.C., Ilgen, D.R. and Klimoski, R.J. (eds.), Handbook of Psychology: Industrial and Organizational Psychology, Vol. 12. Wiley, London, pp. 333-75.

Kozlowski, S.W.J., Toney, R.J., Mullins, M.E., Weissbein, D.A., Brown, K.G. and Bell, B.S. (2001) Developing Adaptability: A Theory for the Design of Integrated-Embedded Training Systems. In Salas, E. (ed.), Advances in Human Performance and Cognitive Engineering Research, Vol. 1. JAI Press, Greenwich, CT, pp. 59-123.

Lorinkova, N.M., Pearsall, M.J. and Sims Jr., H.P. (2013) Examining the Differential Longitudinal Performance of Directive versus Empowering Leadership in Teams. Academy of Management Journal, 56, 573-96.

Marks, M.A., Zaccaro, S.J. and Mathieu, J.E. (2000) Performance Implications of Leader Briefings and Team-Interaction Training for Team Adaptation to Novel Environments. Journal of Applied Psychology, 85, 971-86.

Mathieu, J.E. and Rapp, T.L. (2009) Laying the Foundation for Successful Team Performance Trajectories: The Roles of Team Charters and Performance Strategies. Journal of Applied Psychology, 94, 90-103.

Mathieu, J.E., DeShon, R.P. and Bergh, D.D. (2008) Mediational Inferences in Organizational Research: Then, Now, and Beyond. Organizational Research Methods, 11, 203-23.

Mathieu, J.E., Heffner, T.S., Goodwin, G.F., Salas, E. and Cannon-Bowers, J.A. (2000) The Influence of Shared Mental Models on Team Process and Performance. Journal of Applied Psychology, 85, 27383.

Mathieu, J.E., Rapp, T.L., Maynard, M.T. and Mangos, P.M. (2010) Interactive Effects of Team and Task Shared Mental Models as Related to Air Traffic Controllers' Collective Efficacy and Effectiveness. Human Performance, 23, 22-40.

McGrath, J.E. (1964) Social Psychology: A Brief Introduction. Holt, Rinehart and Winston, New York.
Mohammed, S. and Nadkarni, S. (2011) Temporal Diversity and Team Performance: The Moderating Role of Team Temporal Leadership. Academy of Management Journal, 54, 489-508.

Montoya-Weiss, M.M., Massey, A.P. and Song, M. (2001) Getting It Together: Temporal Coordination and Conflict Management in Global Virtual Teams. Academy of Management Journal, 44, 125162.

Muthén, L.K. and Muthén, B.O. (1998-2010) Mplus User's Guide, 6th edn. Muthén \& Muthén, Los Angeles, CA.

Passos, A.M. and Caetano, A. (2005) Exploring the Effects of Intragroup Conflict and Past Performance Feedback on Team Effectiveness. Journal of Managerial Psychology, 20, 231-44.

Pelled, L.H., Eisenhardt, K.M. and Xin, K.R. (1999) Exploring the Black Box: An Analysis of Work Group Diversity, Conflict, and Performance. Administrative Science Quarterly, 44, 1-28.

Preacher, K.J. and Hayes, A.F. (2008) Asymptotic and Resampling Strategies for Assessing and Comparing Indirect Effects in Multiple Mediator Models. Behavior Research Methods, 40, 879-91.

Rentsch, J.R. and Klimoski, R.J. (2001) Why Do 'Great Minds' Think Alike? Antecedents of Team Member Schema Agreement. Journal of Organizational Behavior, 22, 107-20.

Rentsch, J.R., Delise, L.A., Salas, E. and Letsky, M.P. (2010) Facilitating Knowledge Building in Teams: Can a New Team Training Strategy Help? Small Group Research, 41, 505-23.

Resick, C.J., Murase, T., Bedwell, W.L., Sanz, E., Jiménez, M. and DeChurch, L.A. (2010) Mental Model Metrics and Team Adaptability: A MultiFacet Multi-Method Examination. Group Dynamics: Theory, Research, and Practice, 14, 332-49.

Runco, M.A. and Jaeger, G.J. (2012) The Standard Definition of Creativity. Creativity Research Journal, 24, 92-6.

Salas, E., Sims, D.E. and Burke, C.S. (2005) Is There a 'Big Five' in Teamwork? Small Group Research, 36, 555-99.

Santos, C.M. and Passos, A.M. (2013) Team Mental Models, Relationship Conflict and Effectiveness over Time. Team Performance Management, 19, 363-85.

Santos, C.M., Uitdewilligen, S. and Passos, A.M. (2015) A Temporal Common Ground for Learning: The Moderating Effect of Shared Mental Models on the Relation between Team Learning Behaviours and Performance Improvement. European Journal of Work and Organizational Psychology, 24, 710-25.

Schreiber, J.B., Stage, F.K., King, J., Nora, A. and Barlow, E.A. (2006) Reporting Structural Equation Modeling and Confirmatory Factor Analysis Results: A Review. The Journal of Educational Research, 99, 323-37.

Shah, P.R. and Jehn, K.A. (1993) Do Friends Perform Better Than Acquaintances: The Interaction of Friendship, Conflict, and Task. Group Decision and Negotiation, 2, 149-66.

Simons, T. and Peterson, R. (2000) Task Conflict and Relationship Conflict in Top Management Teams: The Pivotal Role of Intragroup Trust. Journal of Applied Psychology, 85, 102-11. 
Skilton, P.F. and Dooley, K.J. (2010) The Effects of Repeat Collaboration on Creative Abrasion. Academy of Management Review, 35, 118-34.

Spector, P.E. (1997) Job Satisfaction: Application, Assessment, Causes, and Consequences. Sage, Thousand Oaks, CA.

Standifer, R.L., Raes, A.M.L., Peus, C., Passos, A.M., Santos, C.M. and Weisweiler, S. (2015) Time in Teams: Impact of Cognitions and Conflict. Journal of Managerial Psychology, 30, 692708.

Stout, R.J., Cannon-Bowers, J.A., Salas, E. and Milanovich, D.M. (1999) Planning, Shared Mental Models, and Coordinated Performance: An Empirical Link Is Established. Human Factors, 41, 61-71.

Uitdewilligen, S., Waller, M.J. and Pitariu, A.H. (2013) Mental Model Updating and Team Adaptation. Small Group Research, 44, 127-58.

van der Vegt, G.S. and Janssen, O. (2003) Joint Impact of Interdependence and Group Diversity on Innovation. Journal of Management, 29, 729-51.

van Knippenberg, D. and Schippers, M.C. (2007) Work Group Diversity. Annual Review of Psychology, 58, 515-41.

West, M.A. (2002) Sparkling Fountains or Stagnant Ponds: An Integrative Model of Creativity and Innovation Implementation in Work Groups. Applied Psychology: An International Review, 51, 355-424.

West, M.A. and Anderson, N.R. (1996) Innovation in Top Management Teams. Journal of Applied Psychology, 81, 680-93.

Yang, Z. (2009) Temporal Conflict in Teams: Antecedents, Regulatory Mechanisms, and Outcomes. PhD thesis, Pennsylvania State University, University Park, PA.

Catarina Marques Santos (catarina _marques_santos@iscte.pt) is a PhD candidate in the Doctoral Program in Human Resources and Organizational Behavior, at Instituto Universitário de Lisboa (ISCTEIUL), Portugal. Her research focuses on understanding the development of shared mental models, and their impact on team processes and effectiveness over time.

Sjir Uitdewilligen (sjir.uitdewilligen@ maastrichtuniversity.nl) is an assistant professor in Work and Organization Psychology at Maastricht University, The Netherlands. His research focuses on cognition and adaptation in teams and in systems consisting of multiple teams. His work focuses particularly on the temporal dynamics of cognition and adaptation.

Ana Margarida Passos (ana.passos@iscte .pt) is researcher at the Business Research Unit, Instituto Universitário de Lisboa (ISCTE-IUL), Portugal. Her current research interests focus on the social psychological mechanisms underlying team processes and performance in different organizational contexts over time. She is the director of the Human Resources and Organizational Behavior PhD Program at ISCTE-IUL.

\section{Appendix}

Shared mental models scale (based on Cannon-Bowers, Salas \& Converse, 1993)

1. In my team, the team members have a similar understanding about the procedures, strategies and contingency plans involved in decision making.

2. In my team, the team members have a similar understanding of each other's responsibilities, interdependent roles and communication patterns.

3. In my team, the team members have a similar understanding about the technology, resources and tools needed to make decisions.

4. In my team, the team members are familiar with the preferences and abilities of each other. 1995)

Relationship conflict (adapted from Jehn,

1. How much friction is there among members in your team?

2. How much are personality conflicts evident in your team?

3. How much tension is there among members in your team?

4. How much emotional conflict is there among members in your team?

Task conflict (adapted from Jehn, 1995)

1. How often do people in your team disagree about opinions regarding the work being done?

2. How often are there conflicts about ideas in your team?

3. How often are there differences of opinion in your team?

4. How often are there disagreements within you team about the task you are working on?

Process conflict (adapted from Jehn, 1997)

1. How often are there disagreements about resource allocation in your team?

2. How often is there conflict in your team about task responsibilities?

3. How often are there disagreements about the way to complete a certain task? 
4. How often are there disagreements about who should do what in your team?

Temporal conflict (adapted from Yang, 2009)

1. To what extent do team members disagree about time allocation in your work team (how much time to spend on tasks)?

2. To what extent is there conflict about how you should pace task activities in your team?

3. To what extent are there disagreements about how long to spend on specific tasks in your team?

Creativity (adapted from DiLiello, Houghton \& Dawley, 2011). Self-perceived creativity

1. I feel that I am good at generating novel ideas.

2. I have confidence in my ability to solve problems creatively.

3. I have a knack for developing the ideas of others further.

4. I am good at finding creative ways to solve problems.

5. I have the talent and skills to do well in my work.

\section{Creative self-efficacy}

1. I feel comfortable trying out new ideas.

2. I have opportunities to use my creative skills and abilities at work.

3. I am invited to submit ideas for improvements in the workplace.

4. I have the opportunity to participate on team(s).

5. I have the freedom to decide how my job tasks get done.

6. My creative abilities are used to my full potential at work.

Team satisfaction (adapted from Spector, 1997)

How satisfied are you with ...

1. your team?

2. the functioning of your team?

3. your participation in the simulation?

4. the decisions made by your team?

5. communication among your team members?

6. the performance of the team leader?

7. the strategy of your team?

8. the interpersonal relationships among the team members? 